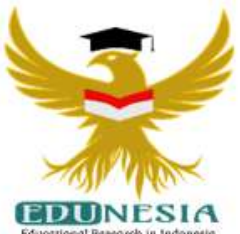

\title{
Pengembangan Lembar Kerja Siswa (LKS) Bernuansa Quantum Teaching Untuk Meningkatkan Minat Dan Hasil Belajar Siswa Kelas IV Di Sekolah Dasar
}

\author{
Desi Widiyanti'; Khairil Hadi ${ }^{2}$ \\ ${ }^{1}$ Pendidikan Guru Sekolah Dasar, STKIP Bina Bangsa Meulaboh, Indonesia \\ 2 Pendidikan Biologi, STKIP Bina Bangsa Meulaboh, Indonesia \\ ${ }^{2}$ Corresponding Email: herilbio@yahooo.co.id, Phone Number : 0853-xxxx-xxxx
}

\begin{abstract}
Article History:
Received: April 25, 2020

Revised: Mei 29, 2020

Accepted: Juni 22, 2020

Published: Juni 24, 2020
\end{abstract}

Keywords:

Interest,

Learning Outcomes,

Quantum Teaching,

Student Worksheets.

\section{Kata Kunci:}

Hasil Belajar, Lembar Kerja Siswa,

Minat,

Quantum Teaching.

\section{How to cite:}

Widiyanti, D. \& Hadi, K. (2020). Pengembangan Lembar Kerja Siswa (Lks) Bernuansa Quantum Teaching Untuk Meningkatkan Minat Dan Hasil Belajar Siswa Kelas IV di Sekolah Dasar. Edunesia : Jurnal Ilmiah Pendidikan, 1 (2): 26-34.

This is an open access article under the $C C-B Y-N C-N D$ license

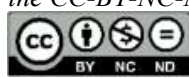

\begin{abstract}
The purpose of this study was to determine the results of the development of LKS nuanced quantum teaching and increased student interest and learning outcomes. This research uses educational development method with 4D Models Thiagarajan, but only consists of 3 (three) stages, namely the defining stage, the planning stage, and the developing and disseminating stages. The population and sample are grade IV students. Data collection instruments used consisted of LKS validation sheets, teacher and student response questionnaires, student interest questionnaires, student interest observation sheets, pretest and posttest. Data analysis uses a Likert scale by changing quantitative values into qualitative values. The results of this study note that the results of the product development in the field of quantum teaching have a very good category so that it is feasible to be used as teaching material in science lessons. Students are very interested in the product development of LKS nuanced quantum teaching as the results of the average percentage of students' interest in LKS is $85.42 \%$. The results of LKS development products have been able to improve student learning outcomes as the results of the average percentage of pretest practice questions by $51.94 \%$ and in posttest practice questions by $73.78 \%$.
\end{abstract}

Abstrak: Tujuan penelitian ini adalah untuk mengetahui hasil pengembangan LKS bernuansa quantum teaching dan peningkatan minat dan hasil belajar siswa. Penelitian ini menggunakan metode pengembangan pendidikan dengan 4D Models Thiagarajan, tapi hanya terdiri dari 3 (tiga) tahap yaitu tahap pendefinisian (define), tahap perencanaan (design), dan tahap pengembangan (develop) dan penyebaran (disseminate). Populasi dan sampel adalah siswa kelas IV. Instrumen pengumpulan data yang digunakan terdiri dari lembar validasi LKS, angket respon guru dan siswa, angket minat siswa, lembar observasi minat siswa, pretes dan postes. Analisis data menggunakan skala likert dengan mengubah nilai kuantitatif menjadi nilai kualitatif. Hasil penelitian ini diketahui bahwa hasil produk pengembangan LKS bernuansa quantum teaching memiliki kategori sangat baik sehingga layak untuk digunakan sebagai bahan ajar pada pelajaran IPA. Siswa sangat berminat terhadap produk pengembangan LKS bernuansa quantum teaching sebagaimana hasil persentase rata-rata minat siswa terhadap LKS yaitu 85,42 \%. Hasil produk pengembangan LKS telah dapat meningkatkan hasil belajar siswa sebagaimana hasil persentase rata-rata soal latihan pretest sebesar $51,94 \%$ dan pada soal latihan postest sebesar 73,78 \%. 


\section{A. Pendahuluan}

Pembelajaran sains sebagai bagian dari proses pendidikan memiliki peran besar dalam upaya pengembangan individu di era global (Hadi, K. 2018). IPA memiliki karakteristik proses atau kerja ilmiah yang didasarkan pada kemampuan berpikir dan penyelesaian masalah karena IPA diperoleh melalui proses penalaran, penyelidikan ilmiah, dan eksperimen dalam menjelaskan gejala alam (Tasiwan dkk, 2014).

Maju dan mundurnya suatu bangsa ditentukan oleh kreativitas pendidikan bangsa itu sendiri dan kompleksnya masalah kehidupan menuntut Sumber Daya Manusia (SDM) yang handal dan mampu berkompetensi (Wahab, 2012). Maka oleh sebab itu, guru harus senantiasa melakukan inovasi dalam proses pembelajaran. Hal senada juga diungkapkan oleh Hadi, K., dkk (2019) bahwa guru sebagai garda terdepan dalam melaksanakan dan atau mengimplementasikan program pemerintah melalui proses belajar mengajar dikelas harus selalu berupaya melakukan inovasi-inovasi. Proses pembelajaran dikatakan efektif apabila terjadi transfer belajar yaitu materi yang disajikan guru dapat diserap ke dalam struktur kognitif peserta didik (Kunandar, 2013). Salah satu untuk mengefektifkan pembelajaran dan supaya proses belajar berjalan degan lancar dan terarah dibutuhkan suatu panduan pelaksanaan kegiatan berupa Lembar Kerja Siswa (LKS).

LKS merupakan salah satu alternatif pembelajaran yang tepat bagi peserta didik karena LKS membantu peserta didik untuk menambah informasi tentang konsep yang dipelajari melalui kegiatan belajar secara sistematis (Mudjiman, 2012). LKS memiliki banyak manfaat, yaitu dapat mengaktifkan siswa selama pembelajaran, membantu siswa dalam mengembangkan konsep, membantu siswa untuk memperoleh informasi, dan meningkatkan minat belajar siswa bila dikembangkan sesuai kebutuhan siswa.

Menurut Prastowo (2011), LKS juga memiliki kegunaan bagi pedidik maupun siswa didalam kegiatan pembelajaran. Bagi pendidik, LKS dapat memberi kesempatan kepada pendidik untuk meningkatkan siswa aktif dan terlibat dengan materi yang dibahas. Karena, menurut penelitian yang dilakukan oleh Syamsu (2017) bahwasannya kurang pahamnya siswa dengan materi yang disajikan pada LKS, disebabkan karena LKS yang digunakan oleh siswa masih terlihat monoton, sehingga siswa cepat merasa bosan dan kurang antusias.

Berdasarkan observasi yang penulis lakukan menunjukkan guru yang mengajar mata pelajaran IPA pada siswa kelas IV di SDN Gunong Keling, masih menggunakan LKS tanpa adanya upaya merencanakan, menyiapkan, dan menyusun sendiri LKS, sehingga pembelajaran yang dilakukan berfokus pada menggunakan LKS yang tersedia dan belum dikembangkan oleh guru sendiri, sehingga siswa kurang berminat terhadap pelajaran IPA karena proses belajar menggunakan LKS yang tidak dikembangkan menjadi sebab banyak siswa tidak memahami isi materi LKS dan soal latihan yang terdapat pada LKS.

Maka dengan dikembangkannya LKS bernuansa quantum teaching oleh penulis sebagai media pembelajaran, maka diharapkan dapat meningkatkan minat siswa IV SDN Gunong Keling terhadap pelajaran IPA. Hal ini sebagaimana penelitian yang dilakukan Sulitstyowati (2014) bahwa dengan adanya LKS berbasis quantum teaching siswa menjadi termotivasi dan memiliki minat belajar karena siswa lebih mudah dan mampu memahami pelajaran.

Pengembangan LKS bernuasa quantum teaching dilakukan penulis karena model pembelajaran quantum teaching merupakan model pembelajaran yang ideal, efektif dan dapat memberikan rasa antusias bagi siswa selama mengikuti pembelajaran. Pemilihan materi pada pelajaran IPA yaitu sifat dan perubahan wujud benda disesuiakan dengan pengembangan LKS bernuansa quantum teaching. Penulis merasa tepat menggunakan 
materi tersebut dalam LKS karena dapat dirasakan langsung dalam kehidupan sehari-hari siswa.

Berdasarkan uraian penjelasan yang telah dikemukakan di atas, maka tujuan penelitian ini adalah untuk menjelaskan proses pengembangan LKS bernuansa quantum teaching pada pelajaran IPA dan juga untuk mengetahui hasil pengembangan LKS bernuansa quantum teaching terhadap peningkatan minat dan hasil belajar siswa pada pelajaran IPA.

\section{B. Metode}

Penelitian yang dilakukan ini hanya 3 (tiga) tahap saja yaitu pendefinisian (define), tahap perencanaan (design), dan tahap pengembangan (develop). Hal ini juga sama halnya dengan penelitian yang dilakukan oleh Kristanti dan Julia (2017) bahwa penelitian pengembangan yang dilakukan hanya terdiri dari 3 (tiga) tahap yaitu pendefinisian (define), tahap perencanaan (design), tahap pengembangan (develop).

Populasi penelitian ini adalah siswa kelas IV semester I tahun ajaran 2018/2019 di Sekolah Dasar Negeri Gunong Kleng Kecamatan Meureubo Kabupaten Aceh Barat. Adapun Sampel penelitian adalah keseluruhan populasi yang diteliti yaitu siswa kelas IV semester I tahun ajaran 2018/2019 di Sekolah Dasar Negeri Gunong Kleng Kecamatan Meureubo Kabupaten Aceh Barat.

Berdasarkan tahap penelitian tersebut maka, proses penelitian ini yaitu pada tahap define (pendefinisian) dilakukan dengan analisis awal, analisis peserta didik, analisis tugas, analisis konsep dan merumuskan tujuan pembelajaran. Pada tahap design (perancangan) dilakukan penyusunan instrumen, pemilihan bahan ajar, pemilihan format dan rancangan produk awal. Tahap develop (pengembangan) meliputi tahap penilaian ahli dan uji coba pengembangan. Tahap terkahir adalah tahap disseminate (penyebaran). Tahap disseminate merupakan tahap penggunaan perangkat yang telah dikembangkan pada skala yang lebih luas misalnya di kelas lain, di sekolah lain, dan oleh guru lain. Tujuan penelitian ini adalah menghasilkan model lembar kerja siswa berupa LKS Bernuana quantum teaching untuk meningkatkan minat belajar siswa.

Pengumpulan data pada penelitian ini terdiri dari:

1. Lembar validasi LKS untuk memperoleh data dari dosen ahli materi, dan guru sebagai bahan mengevaluasi LKS.

2. Angket respon peserta didik untuk mengetahui respon peserta didik terhadap produk LKS yang dikembangkan.

3. Angket minat siswa untuk mengetahui minat siswa terhadap produk LKS yang dikembangkan.

4. Tes hasil belajar disusun untuk mengetahui minat peserta didik terdiri dari soal pretest dan posttest yang disajikan oleh penulis dalam LKS.

5. Lembar observasi minat siswa untuk mengetahui minat siswa selama proses pembelajaran dengan menggunakan LKS yang dikembangkan.

Data yang diperoleh dan dikumpulkan dari beberapa instrumen pada penelitian ini akan dianalisis sebagai berikut:

\section{Analisis Validasi Kelayakan LKS}

Validasi LKS bernuansa quantum teaching dianalisis dengan mencari rata-rata penilaian antara penilai. Perolehan rata-rata skor dari setiap komponen aspek penilaian dengan menggunakan rumus: 
$\mathrm{X}=$ Rerata skor

$$
\bar{X}=\frac{\sum X}{n}
$$

$\sum \mathrm{X}=$ Jumlah total skor tiap komponen

$\mathrm{n}=$ Jumlah validator

Selanjutnya, semua data yang sudah diperoleh pada tiap butir penilaian kemudian dijumlah disebut sebagai skor aktual $(X)$. Skor aktual yang bersifat kuantitatif ini diubah menjadi nilai kualitatif dengan berpedoman pada konversi skor untuk mengetahui kelayakan kualitas yang dikembangkan. Acuan pengubahan skor dapat dilihat pada tabel sebagai berikut:

\section{Tabel 1.}

Konversi Skor Aktual Menjadi Nilai Skala Empat

\begin{tabular}{clcc|}
\hline No & \multicolumn{1}{c}{ Rentang Skor } & Nilai & Kategori \\
\hline 1 & $\mathrm{X}>\overline{\mathrm{X}}+1 . \mathrm{SBx}$ & $\mathrm{A}$ & $\begin{array}{c}\text { Sangat } \\
\text { Baik }\end{array}$ \\
\hline 2 & $\overline{\mathrm{X}}+1 . \mathrm{SB}>X \geq \overline{\mathrm{X}}$ & $\mathrm{B}$ & Baik \\
\hline 3 & $\overline{\mathrm{X}}>X \geq-1 . S B \mathrm{x}$ & $\mathrm{C}$ & Cukup \\
\hline 4 & $\mathrm{X}<\overline{\mathrm{X}}-1 \mathrm{SBx}$ & $\mathrm{D}$ & Kurang \\
\hline
\end{tabular}

Sumber: Widoyoko (2009)

Keterangan:

$\mathrm{X}=$ Skor aktual skor yang dicapai

$\overline{\mathrm{X}} \quad=$ Rerata skor ideal $(1 / 2$ (skor tertinggi ideal + skor terendah ideal)

SBx $=$ Simpangan baku skor ideal $=1 / 6$ (skor tertinggi ideal - skor terendah ideal)

Skor tertinggi ideal $=\sum$ butir kriteria $x$ skor tertinggi

Skor terendah ideal $=\sum$ butir kriteria $\mathrm{x}$ skor terendah

Berdasarkan tabel di atas, maka nilai kelayakan produk dalam penelitian ini akan ditentukan dengan nilai minimum " $\mathrm{C}$ " dengan kategori cukup baik. Jadi jika hasil penilaian oleh para ahli dan guru IPA reratanya memberikan hasil akhir minimal "C" maka produk LKS bernuansa quantum teaching ini layak digunakan.

\section{Analisis Hasil Respon Peserta Didik terhadap LKS}

Respon peserta didik setelah siswa menggunakan LKS dikembangkan harus melakukan pengubahan nilai kualitatif menjadi nilai kuantitatif dimana semua data yang diperoleh dari penilaian menggunakan skala likert. Skor total rata-rata dari setiap komponen dapat dihitung dengan rumus:

$$
x_{i}=\frac{\text { Jumlah skor setiap indikator }}{\text { Jumlah aspek indikator yang dinilai }}
$$

3. Analisis Minat terhadap LKS

Minat siswa terhadap LKS bernuansa quantum teaching harus melakukan pengubahan nilai kualitatif menjadi nilai kuantitatif dimana semua data yang diperoleh dari penilaian 
menggunakan skala likert. Skor total rata-rata dari setiap komponen dapat dihitung dengan menggunakan rumus:

$$
x_{i}=\frac{\text { Jumlah skor setiap indikator }}{\text { Jumlah aspek indikator yang dinilai }}
$$

4. Analisis Hasil Belajar Siswa

Analisis hasil belajar bertujuan untuk memperoleh data tentang penguasaan materi LKS yang dikembangkan setelah siswa mempelajari LKS. Hasil belajar ini diukur dari soal latihan yang terdapat dalam LKS. Soal latihan pretest diberikan di sebelum LKS dipelajari oleh siswa, sedangkan soal postes diberikan setelah siswa mempelajari LKS bernuansa quantum teaching. Penilaian hasil belajar tersebut menggunakan rumus sebagai berikut:

$$
N=\frac{\text { Skor Siswa }}{\text { Jumlah Aspek Penilaian }} \times 100
$$

\section{Hasil dan Pembahasan}

1. Hasil Validasi LKS Bernuansa Quantum Teaching oleh Ahli

Penelitian ini merupakan penelitian pengembangan produk bahan ajar LKS bernuansa quantum teaching yang dikembangkan terhadap mata pelajaran IPA pada materi sifat dan perubahan wujud benda. Uji validasi terhadap produk akhir pengembangan LKS bernuansa quantum teaching merupakan bagian dari tahapan hasil konsultasi terhadap dosen ahli yang mana penyajian isi LKS menitikberatkan pada beberapa aspek isi yang disajikan dan penggunaan bahasa LKS. Ahli materi yang menjadi validator produk LKS yang berkompeten sesuai terhadap materi yang ada pada LKS Instrumen validasi telah disusun menggunakan skala (1-4) untuk menilai hasil dari kelayakan hasil produk LKS.

Tabel 2.

Hasil Validasi Kelayakan Terhadap Produk Pengembangan LKS

\begin{tabular}{|ccccc}
\hline No & $\begin{array}{c}\text { Aspek } \\
\text { Penilaian }\end{array}$ & $\begin{array}{c}\text { Perolehan Skor } \\
\text { Validator } \\
\text { I }\end{array}$ & $\begin{array}{c}\text { Validator } \\
\text { II }\end{array}$ & $\begin{array}{c}\text { Total } \\
\text { Skor }\end{array}$ \\
\hline 1 & $\begin{array}{l}\text { Isi yang } \\
\text { Disajikan }\end{array}$ & 22 & 23 & 45 \\
\hline 2 & Bahasa & 20 & 19 & 39 \\
\hline Skor $\sum X$ & 42 & 42 & 84 \\
\hline Rata aktual $(X)$ & & 42 \\
\hline \multicolumn{2}{l}{ Rerata skor ideal $(\bar{X})$} & 24 \\
\hline Simpangan baku skor ideal $(\mathrm{SBx})$ & 6,7 \\
\hline
\end{tabular}

Aspek yang dinilai oleh ahli materi ada 2 aspek dengan jumlah indikator 11 butir. Jumlah skor yang diperoleh dari validasi oleh validator I adalah 42 dan validasi oleh validator II adalah 42 sehingga diperoleh total skor adalah 84 dan jumlah skor aktual yaitu 42.

Berdasarkan hasil konversi skor aktual dari tabel di atas maka hasil dari validasi kelayakan produk LKS bernuansa quantum teaching sebesar 42 berada pada rentang skor $X$ $\geq 24+7,6$ sehingga untuk aspek penilaian produk LKS bernuansa quantum teaching masuk 
ke dalam kategori sangat baik untuk digunakan sebagai bahan pembelajaran IPA dengan materi sifat dan perubahan wujud benda pada siswa kelas IV SD Negeri Gunong Keling Kabupaten Aceh Barat.

\section{Respon Guru terhadap LKS Bernuansa Quantum Teaching}

Setelah angket divalidasi, maka angket respon guru tersebut diberikan kepada guru yaitu ibu Mustia Diana Kamal, S.Pd selaku Wali kelas IV SD Negeri Gunong Keling Kabupaten Aceh Barat yang berkompeten sesuai terhadap materi yang ada pada LKS. Berdasarkan angket yang telah diberikan, maka diperoleh skor pada setiap aspek penilaian sebagai berikut:

Tabel 3.

Respon Guru terhadap LKS

\begin{tabular}{|clc|}
\hline No & \multicolumn{1}{c}{ Aspek Penilaian } & Skor \\
\hline 1 & $\begin{array}{l}\text { LKS sudah memenuhi Komponen dalam syarat yaitu nomor, isi, judul } \\
\text { kegiatan, dan tujuan sesuai dengan KD }\end{array}$ & 4 \\
\hline 2 & $\begin{array}{l}\text { Kejelasan petunjuk dan arahan pengisian LKS dapat dipahami oleh } \\
\text { siswa }\end{array}$ & 3 \\
\hline 3 & Kejelasan tulisan pada LKS & 3 \\
\hline 4 & $\begin{array}{l}\text { Kesesuaian materi pada LKS dengan materi pokok dalam Kompetensi } \\
\text { Dasar (KD) }\end{array}$ & 4 \\
\hline 5 & $\begin{array}{l}\text { Kesesuaian materi yang disajikan pada LKS dengan tujuan pembelajaran } \\
\text { yang akan dicapai }\end{array}$ & 4 \\
\hline 6 & \begin{tabular}{l} 
Penyajian LKS dilengkapi dengan gambar dan ilustrasi \\
\hline 7
\end{tabular} & $\begin{array}{l}\text { Gambar yang tercantum dalam LKS jelas dan mudah dipahami oleh } \\
\text { siswa }\end{array}$ \\
\hline 8 & \begin{tabular}{l} 
Pengguna bahasa sesuai dengan EYD \\
\hline
\end{tabular} & 4 \\
\hline
\end{tabular}

Sumber: Pengolahan Hasil Penelitian (Tahun 2018)

Berdasarkan tabel di atas diketahui bahwa aspek yang harus dinilai sebagai bentuk respon guru terhadap hasil produk pengembangan LKS bernuansa quantum teaching berjumlah indikator 8 penilaian. Jumlah skor yang diperoleh dari hasil respon gutu di atas adalah 30. Hasil konversi terhadap interval respon guru yaitu rentang skor 1-8 = kurang baik, rentang skor 9-16= cukup, rentang skor 17-24 = baik dan rentang skor 25-32= sangat baik. Maka berdasarkan rentang skor tersebut diketahui bahwa hasil respon guru terhadap pengembangan LKS bernuansa quantum teaching berada dalam kategori sangat baik sehingga pengembangan LKS bernuansa quantum teaching yang telah disusun oleh penulis dapat digunakan untuk mata pelajaran IPA pada siswa kelas IV SD Negeri Gunong Keling Kabupaten Aceh Barat.

\section{Respon Siswa terhadap LKS Bernuansa Quantum Teaching}

Berdasarkan penyebaran angket respon, maka diperoleh hasil penelitian respon siswa terhadap LKS bernuansa quantum teaching bahwa bahwa terdapat 13 indikator aspek penilaian terkait dengan respon siswa terhadap LKS bernuansa quantum teaching, maka jumlah skor rerata yang diperoleh dari hasil respon siswa adalah 45,39 . Hasil konversi terhadap interval respon 
siswa yaitu pada rentang skor $1 \%-24,5 \%=$ sangat tidak setuju, rentang skor $25 \%-40,5=$ tidak setuju, rentang skor $50 \%-74,5 \%=$ setuju dan rentang skor $75 \%-100 \%=$ sangat setuju.

Berdasarkan rentang skor tersebut diketahui bahwa hasil respon siswa terhadap LKS bernuansa quantum teaching diperoleh rata-rata skor sebesar 45,39 dan persentase sebesar 87,29 \%. Dengan memperhatikan hasil persentase dari angket respon siswa menunjukkan bahwa respon siswa terhadap LKS bernuansa quantum teaching yang telah dikembangkan berada dalam kategori sangat setuju sehingga LKS yang telah dikembangkan ini layak diberikan kepada siswa untuk mengetahui minat siswa terhadap LKS bernuansa quantum teaching.

\section{Minat Siswa terhadap LKS Bernuansa Quantum Teaching}

Berdasarkan hasil pengisian angket minat siswa bahwa indikator aspek minat siswa terhadap LKS bernuansa quantum teaching, maka jumlah skor rerata yang diperoleh dari pengisian angket minat siswa adalah 34,22. Hasil konversi terhadap interval respon siswa yaitu rentang skor $1 \%-24,5 \%$ = sangat tidak berminat, rentang skor $25 \%-40,5=$ tidak berminat, rentang skor $50 \%-74,5 \%$ = beminat dan rentang skor $75 \%-100 \%=$ sangat berminat.

Berdasarkan rentang skor tersebut diketahui bahwa minat siswa terhadap LKS diperoleh persentase rata-rata yaitu 85,42\%. Dengan demikian siswa sangat berminat terhadap LKS yang dikembangkan sebagai bahan pengajaran mata pelajaran IPA pada materi sifat dan perubahan wujud benda di kelas IV SD Negeri Gunong Keling Kabupaten Aceh Barat.

\section{Observasi Minat Siswa terhadap Pengembangan LKS}

Berdasarkan pengamatan terhadap siswa yang telah mengikuti pembelajaran dengan menggunakan LKS bernuansa quantum teaching telah dapat membantu meningkatkan minat siswa untuk belajar IPA pada materi sifat dan perubahan wujud benda. Hal tersebut dapat dilihat pada grafik berikut ini:

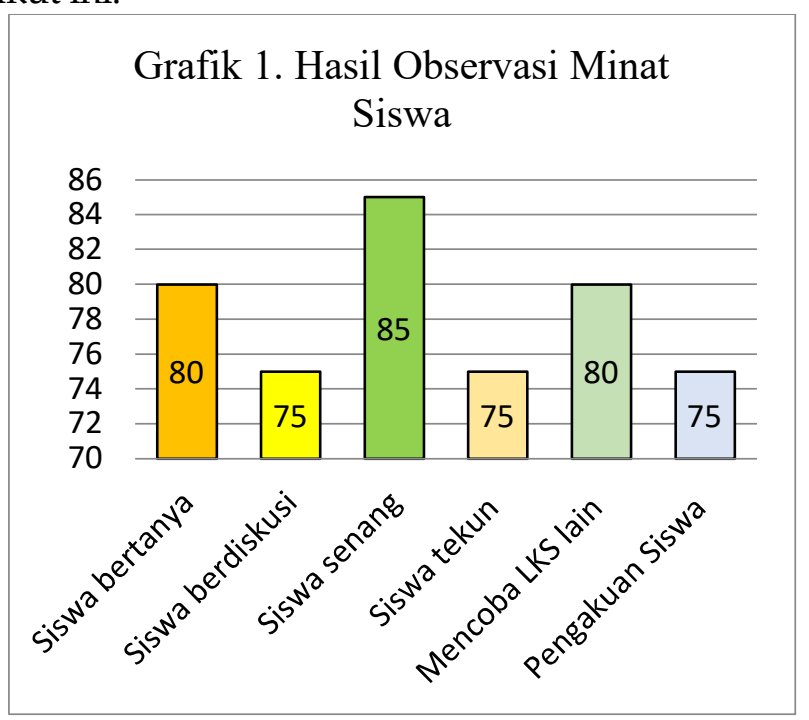

Gambar 1. Hasil Observasi Minat Siswa

Berdasarkan grafik di atas, diketahui skor penilaian yang diberikan penulis terhadap observasi siswa bertanya yaitu 80 , siswa berdiskusi yaitu 75 , siswa senang yaitu 85 , siswa tekun yaitu 75, mencoba LKS lain yaitu 80 dan pengakuan siswa yaitu 75. Dari data 
pengamatan siswa yang berupa data kualitatif tersebut kemudian dipersentasikan dengan rumus berikut:

$$
P=\frac{\sum \text { Skor Perolehan }}{\sum \text { Skor Total }} \times 100 \%
$$

Berdasarkan perhitungan rumus persentase terhadap observasi minat siswa maka diperoleh rata-rata persentase minat siswa terhadap LKS bernuansa quantum teaching yaitu 78 $\%$. Adapun persentase untuk setiap rata-rata indikator minat siswa diketahui siswa bertanya yaitu $80 \%$, siswa berdiskusi yaitu $75 \%$, siswa senang yaitu $85 \%$, siswa tekun yaitu $75 \%$, mencoba LKS lain yaitu $80 \%$ dan pengakuan siswa yaitu $75 \%$.

\section{Hasil Belajar Siswa}

Data hasil belajar siswa dari soal latihan yang sudah dicantumkan dalam LKS bernuansa quantum teaching menunjukkan sebelum produk LKS diberikan hasil belajar siswa pada soal latihan pretest menunjukkan nilai rata-rata yaitu 51,94. Sedangkan setelah LKS bernuansa quantum teaching diberikan kepada siswa, kemudian setelah peserta didik mempelajarinya dengan seksama, mengadakan tanya jawab bersama penulis ketika siswa mempelajari LKS, maka hasil belajar siswa pada soal latihan postest telah menunjukkan adanya peningkatan dengan nilai rata-rata yaitu 73,78. Adapun perbandingan hasil belajar siswa dilihat dari hasil pretest dan postest tabel di atas dapat dibuat perbandingan sebagaimana dapat dilihat pada grafik berikut ini:

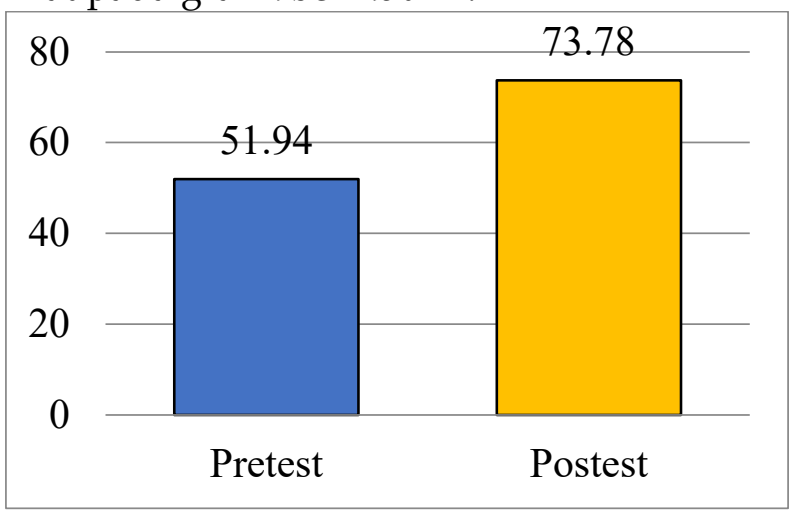

Gambar 2. Hasil Belajar.

Berdasarkan perhitungan rumus, maka peningkatan hasil belajar siswa maka diperoleh rata-rata persentase pada soal latihan pretest sebesar $51,94 \%$ dan pada soal latihan postest sebesar 73,78 \%. Dengan demikian adanya LKS bernuansa quantum teaching selain dapat meningkatkan minat siswa, maka telah dapat meningkatkan hasil belajar siswa kelas IV Sekolah Dasar Negeri Gunung Keling pada mata pelajaran IPA materi sifat dan perubahan wujud benda.

\section{Kesimpulan}

Berdasarkan hasil penelitian yang telah dilakukan, penelitian ini dapat disimpulkan sebagai berikut:

1. Hasil produk pengembangan LKS bernuansa quantum teaching memiliki kategori sangat baik sehingga layak untuk digunakan sebagai bahan ajar pada pelajaran IPA. Hasil validasi kelayakan LKS juga didukung oleh respon guru yang menunjukkan bahwa LKS 
bernuansa quantum teaching memiliki kategori sangat baik untuk disebarkan kepada siswa kelas IV SD Negeri Gunong Keling Kabupaten Aceh Barat.

2. Siswa sangat berminat terhadap produk pengembangan LKS bernuansa quantum teaching sebagaimana hasil persentase rata-rata minat siswa terhadap LKS yaitu 85,42\%. Hasil produk pengembangan LKS telah dapat meningkatkan hasil belajar siswa sebagaimana hasil persentase rata-rata soal latihan pretest sebesar $51,94 \%$ dan pada soal latihan postest sebesar $73,78 \%$. Dengan demikian, LKS bernuansa quantum teaching telah dapat meningkatkan minat siswa dan hasil belajar siswa kelas IV SD Negeri Gunong Keling Kabupaten Aceh Barat.Saran disusun berdasarkan temuan penelitian yang telah dibahas. Saran dapat mengacu pada tindakan praktis, pengembangan teori baru, dan/atau penelitian lanjutan.

\section{Daftar Pustaka}

Hadi, K. (2018). Pengembangan model problem based learning Berbasis kearifan lokal pada materi Keanekaragaman hayati kelas X Di kabupaten aceh selatan. Jurnal Bionatural , 4 (2), $42-52$

Hadi, K., Dazrullisa, D., Hasruddin, H \& Manurung, B. (2019). The Effect of Teaching Materials Based on Local Value Integrated by Character Education through PBL Models on Students' High Order Thinking Skill. Britain International of Humanities and Social Sciences (BIoHS) Journal. Vol. 1, No. 2, October 2019, Page: 213-223. doi:http://doi.org/10.33258/biohs.v1i2.54

Kristanti, D. \& Julia, S. (2017). Pengembangan Perangkat Pembelajaran Matematika Model 4-D Untuk Kelas Inklusi Sebagai Upaya Meningkatkan Minat Belajar Siswa. Jurnal Maju, Vol. 4 No 1. Maret 2017.

Kunandar. (2013). Penilaian Autentik (Penilaian Hasil Belajar Peserta Didik Berdasarkan Kurikulum 2013). Jakarta: Rajawali Pers.

Mudjiman. (2012). Belajar Mandiri. Surakarta: LPP UNS dan UNS Press.

Prastowo, A. (2011). Panduan Kreatif Membuat Bahan Ajar Inovatif. Jogjakarta: DIVA Press.

Sulitstyowati. (2014). Pengembangan Lembar Kerja Siswa (LKS) Materi Bangun Datar Segiempat Berbasis Quantum Teaching Pada Siswa Kelas VI. Tesis Universitas Muhammadiyah Purwokerto.

Syamsu, F.D. (2017). Pengembangan LKS Biologi Berbasis Kontekstual Dilengkapi Dengan Mind Map Pada Materi Archaebacteria Dan Eubacteria Untuk Siswa SMA. Jurnal Bionatural, Volume 4 No. 1, Maret 2017.

Wahab. (2012). Memahami Pendidikan dan Ilmu Pendidikan. Yogyakarta : CV Aswaja Pressindo.

Widoyoko, S. (2009). Evaluasi Program Pembelajaran. Yogyakarta: Pustaka Pelajar 